\title{
CONDITIONS OF TERRITORIAL ACCESSIBILITY OFFERED BY THE NETWORK OF SUSTAINABLE TOURISM ROUTES THAT ARE PART OF THE COFFEE CULTURAL LANDSCAPE - COLOMBIA
}

\author{
Alejandra ORJUELA \\ Universidad Nacional de Colombia, Facultad de Ingeniería y Arquitectura, Departamento de Ingeniería \\ Civil, Sustainable Mobility Research Group (GIMS), Career 37 Street 94, CP 170003, Manizales, Colombia, e-mail: aorjuelay@unal.edu.co \\ Diego Alexander ESCOBAR* \\ Universidad Nacional de Colombia, Facultad de Ingeniería y Arquitectura, Departamento de Ingeniería \\ Civil, Sustainable Mobility Research Group (GIMS), Career 37 Street 94, CP 170003, Manizales, Colombia, e-mail: daescobarga@unal.edu.co
}

\section{Carlos Alberto MONCADA}

Universidad Nacional de Colombia, Facultad de Ingeniería, Departamento de Ingeniería Civil y Agrícola. Research in Transport and transtit (PIT), Career 35 Street 26, CP 111321, Bogotá, Colombia, e-mail: camoncadaa@unal.edu.co

\begin{abstract}
Citation: Orjuela, A., Escobar, D.A., \& Moncada, C.A. (2020). CONDITIONS OF TERRITORIAL ACCESSIBILITY OFFERED BY THE NETWORK OF SUSTAINABLE TOURISM ROUTES THAT ARE PART OF THE COFFEE CULTURAL LANDSCAPE - COLOMBIA. GeoJournal of Tourism and Geosites, 32(4), 1290-1298. https://doi.org/10.30892/gtg.32415-571
\end{abstract}

\begin{abstract}
Tourist attraction is related to the provision of services in an urban or rural environment; it is possible to find the relationship between the tourist potential and performance infrastructure that provides access to the points. Aims: Asses accessibility of the routes that make part of the Coffee Cultural Landscape (CCL). Method: accessibility models based on isochronous curves obtained in the analysis of travel time, which allows the determination of population covered by the curves. Results: There is no direct relationship between the sociodemographic and socioeconomic variables, due to the low participation of the tourism in the GDP of the CCL.
\end{abstract}

Key words: Coffee Cultural Landscape, Accessibility, Transport Models, Tourist Routes

$$
* \quad * \quad * \quad * \quad * *
$$

\section{INTRODUCTION}

The Coffee Region is part of the so-called Andean Region and is located in the center of western Colombia, 5-28-18" north latitude and 75-40-54" west longitude (Figure1). Risaralda, Caldas, Quindío, and northern Valle del Cauca are the departments that make up Colombian Coffee Cultural Landscape, which are between 1,200 and 2,200 meters above sea level. This region is home to a total of 3,282,702 inhabitants (NADS - National Administrative Department of Statistics, 2019), in an area of 19,834 $\mathrm{km}^{2}$, of which $17.56 \%$ corresponds to the territory declared as Coffee Cultural Landscape (CCL) of Colombia. The climatic conditions of the study area are between $-8^{\circ} \mathrm{C}$ and $29^{\circ} \mathrm{C}$, due to the existence of snow and tropical forests in the region (Ministry of Culture, 2011). This wide variability, along with the geology of the area, gives way to the production of high-quality coffee in short harvest periods, which has placed the region as one of the worldwide best-known territories for its grain quality and how its production process is carried out. This, together with the communities' architectural values, customs, and traditions, has positioned the region as a tourist-friendly territory.

The Coffee Cultural Landscape corresponds to a territory comprised of 47 municipalities and 411 villages (geographical unit corresponding to the minimum territorial division of Colombia). This takes place in a territory of more than 141 thousand hectares in the main area and 207 thousand in buffer zones, which consist of villages that surround the main area of the landscape, allowing the conservation and protection of the Exceptional Universal Value of the declared heritage zone (Ministry of Culture, 2011, http://paisajeculturalcafetero.org.co/static/files/cartillaministerio.pdf.pdf).The Coffee Cultural Landscape has been worthy of this declaration for being an example of a sustainable and productive landscape. It has been adapted to difficult geographical conditions developing coffee cultivation on hillsides and mountains, establishing exceptional models of collective work to cope with difficult economic situations. The construction techniques in both urban and rural areas stand out, which corresponds to the cultural heritage architectural material and the large number of fairs, festivals, and events that are held around the cultivation of coffee as an intangible cultural heritage (Ministry of Culture, 2009, http://paisajeculturalcafetero.org.co/contenido/Plan-de-Manejo-del-PCC).

Despite efforts to raise awareness of the region's tourist attraction, it is hypothesized that the current transport infrastructure provides deficient geographical accessibility to the region. This directly impacts domestic tourism development, which has shown a ste ady increase in recent years due to the varied cultural, gastronomic, and landscape opportunities.

The statistical information, shown in the receiving tourism report for the Coffee Region of May 2019 (CCL Tourist Information System SITUR FONTUR, 2019), indicates that holidays, recreation, and leisure activities are the main reasons for tourists to travel to that territory. Concerning municipalities in May 2019, Pereira was placed as the most visited city (19.3\%), followed by Salento (14.5\%), Manizales (14.3\%), Filandia (13.2\%), Montenegro (11.6\%), Armenia (10.5\%), Santa Rosa de Cabal (6.9\%), Quimbaya (3.7\%), Calarcá (2\%), others (4\%); Also, $89.6 \%$ of surveyed visitors were born in another department in Colombia, followed by $7.6 \%$ born in the Coffee Cultural Landscape region and 2.8\% born abroad, with a total of 26,064 visitors in the Coffee Axis Region between January and May 2019.

From the above statistical information, it is possible to observe that the highest visitors percentage of the Coffee Cultural Landscape region are national, however, only $7.6 \%$ correspond to the population that inhabits the Coffee Region (CCL Tourist Information System - SITUR FONTUR, 2019), which could represent some degree of inequity in terms of accessibility conditions to the regional tourist environment for the locals ; it is also observed that the largest percentage of visited municipalities corresponds to those of Quindío department, leaving aside the tourist attraction offered by Caldas, Risaralda, and Northern Valle del Cauca municipalities, except their capitals. 


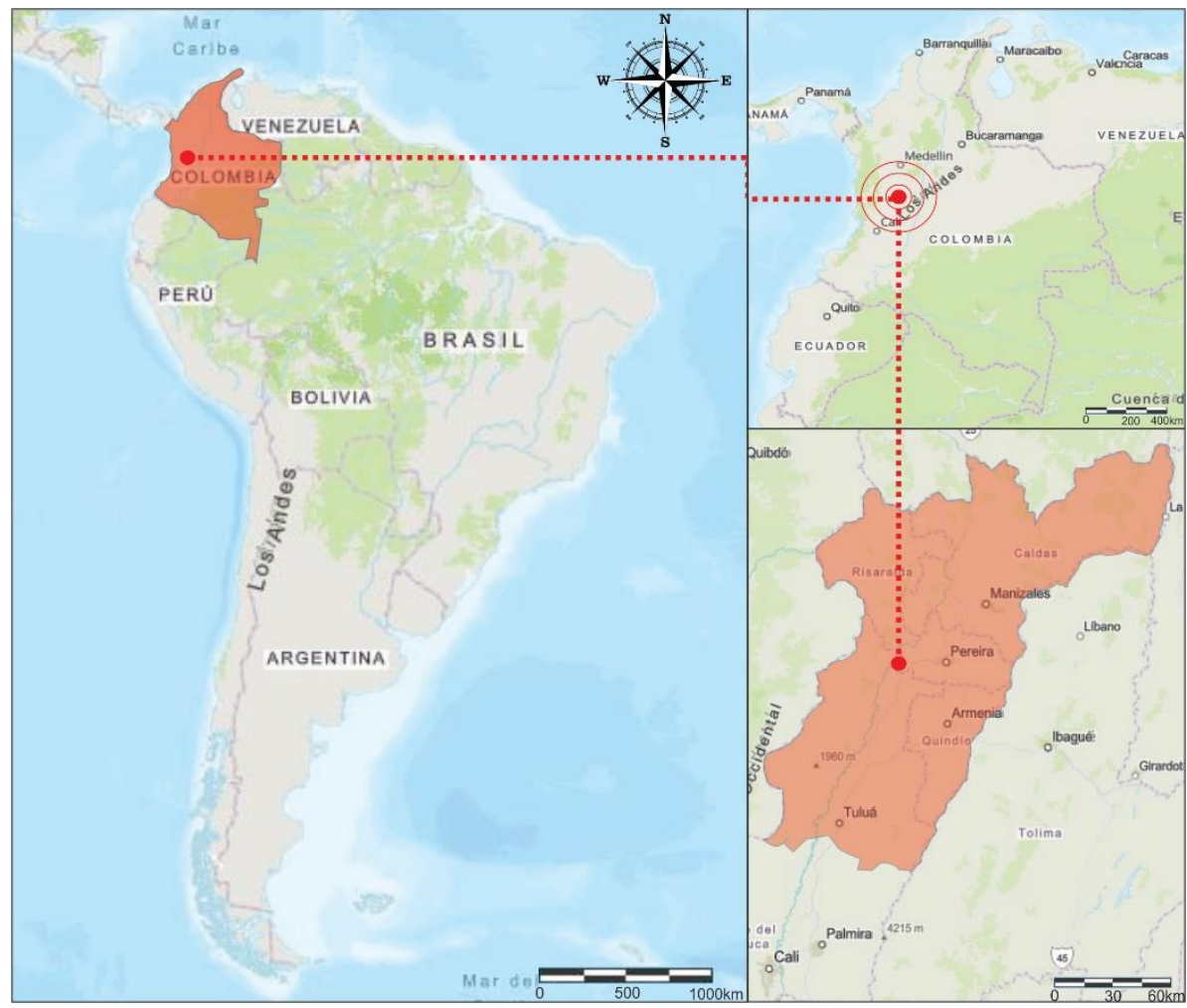

Figure 1. Geographic location of the area

This research seeks to identify the territorial accessibility conditions currently offered by the tourist routes that are part of the Coffee Cultural Landscape, which have been set by the Colombian Ministry of Commerce, Industry, and Tourism. So that it is possible to establish the relationship between the tourist potential of the region, the infrastructure characteristics that provide access to the different tourist points of interest, and the Coffee Region and Northern Valle del Cauca inhabitant socio-economic conditions. It is based on the hypothesis that tourist attraction is directly related to the provision of goods, equipment, services, and accessibility in either an urban or rural environment.

One of the first technical definitions of the term accessibility emerged in 1959, linked to the activity distribution measurement concerning their location, in agreement with the willingness and ease that both people and companies have to overcome the spatial barrier (Hansen, 1959). This concept can also be observed with an approach to access to opportunities, defined as "the degree of adjustment between mobility opportunity structures and the resources available to households to take advantage of them" (Hernández, 2012). The research carried out by Ingram (1971) is based on the application of the concept of accessibility in urban environments; the author establishes the difference between the relative accessibility from two points and the integral accessibility at one, identifying the operational modes of these definitions, applied to the urban area of Hamilton, Ontario and obtains, as a result, that the Gaussian curve is the one that best fits the integral mobility calculation, which is given as the degree of interconnection of one point with others in the same area or territory, such as measuring the connection of a fire station or hospital, with the other nodes that comprise a city's network (Ingram, 1971).

Additionally, the concept of global average accessibility arises, which is considered in terms of time or distance from all the network nodes to all nodes. Dijkstra's graph theory and the minimum path algorithm is used to calculate it (Dijkstra, 1959), which consists of obtaining the travel matrix from minimizing the variable time or distance (Delling et al., 2009; Bauer et al., 2010).

The analysis of territorial accessibility widely used at the international level can be addressed from such diverse angles as tourism development (López et al., 2011), problem-solving of inequity and social exclusion (Lucas, 2012; Lucas et al., 2016; Oviedo et al., 2019), generation of public policies (Beria et al., 2017; Hernandez et al., 2018; Xiao et al., 2017), analysis of road safety (Tiwari and Jain, 2012), economic development, and transport systems (Yigitcanlar et al., 2007), and also access to services such as libraries (Higgs et al., 2018), education (Walsh et al., 2017), and health (Rosero-Bixby, 2004). In recent years, this concept has been applied in case studies that have allowed the decision-making supported technically. In Colombia, this methodology implementation for the territorial accessibility calculation has gain strength from research that has shown that its use can withstand decision-making regarding the introduction of road infrastructure interventions, since it allows us to determine the areas that need to optimize their accessibility to improve the region's inhabitant's quality of life, according to land uses (Escobar and García, 2012; Escobar et al., 2013).

At a regional level, research has been carried out to evaluate the application of accessibility concepts, which may reflect needs in the operational changes of a transport service (Escobar et al., 2018; Guzman et al., 2018; Montoya et al., 2017). The authors Escobar García and Urazán Bonells (2014) describe the state-of-the-art accessibility at a worldwide level and show the general methodology of application, to demonstrate the different possibilities offered by this territorial planning instrument, based on the geostatistical analysis of geographic location data, operational and topological characteristics of the analyzed network (Escobar and Urazán, 2014).

Currently, several studies have been focused on the empirical analysis of the correlation between territorial accessibility, transport, and tourism development of regions. One of these is carried out by Celata (2007), which evaluates the case of the southern Italian region known as Mezzogiorno, to set the extent to which accessibility can represent a limit for the development of tourism in peripheral and remote areas. This is to establish a basis that tourism is linked to the transport system development and the reduction of economic distances (Celata, 2007).

Kastenholz et al., 2012 show in their research applied to a small tourist area called Louso in Portugal, that tourist destinations face intense and growing competition worldwide with increasingly demanding consumers who require not only service quality, but also socially responsible and sustainable locations. Therefore, tourism development with a focus on the accessibility provided can contribute to increasing the competitiveness of the destination area and create a culture of social responsibility. 
The use of Geographic Information Systems (GIS) for the calculation of territorial accessibility is based on the ease of these tools to process spatial and socioeconomic information involving complex computations (Liu and Zhu, 2004).

\section{MATERIAL AND METHODS}

The research methodology is shown in Figure 2. This consists of 6 consecutively developed stages, which are described below.

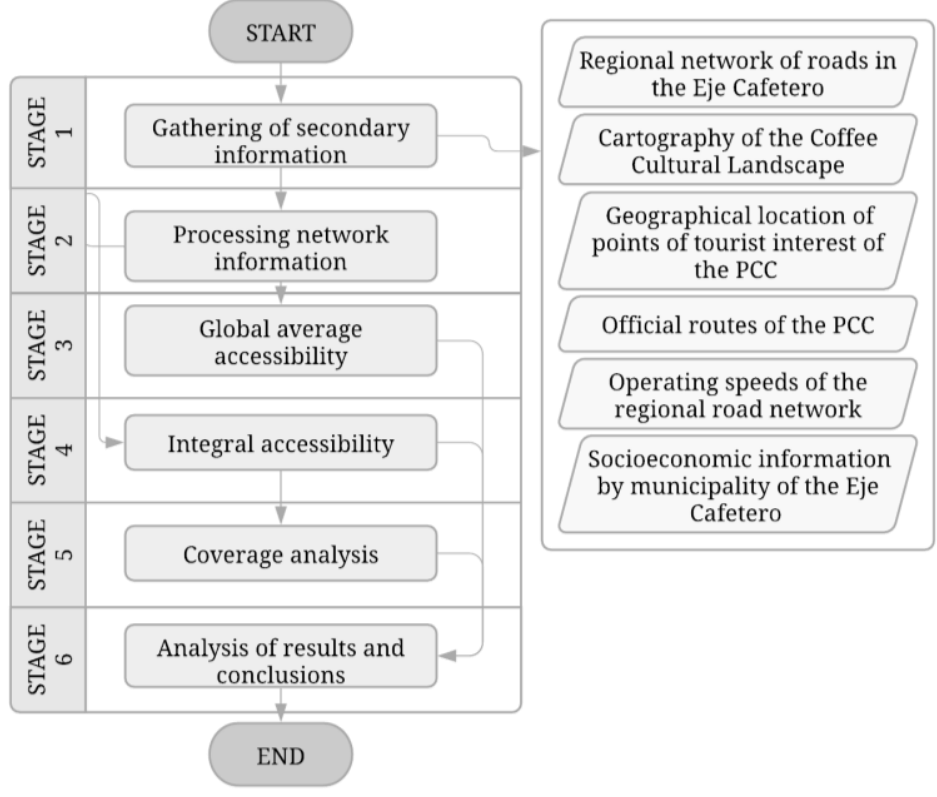

Figure 2. Research methodology

Collecting secondary information: In this stage, the necessary secondary information is collected for the development of the research, which consists of a regional network of roads in the Coffee Region and Northern Valle del Cauca, geographic delimitation of the Coffee Cultural Landscape, georeferencing of the points of interest and official routes of the Landscape, operating speeds of the primary and secondary roads in the region, sociodemographic and socioeconomic information by the municipality. The sociodemographic information of the municipalities of the Coffee Region and Northern Valle del Cauca is obtained from the population projections 2018 - 2020, municipal total by area of the National Administrative Department of Statistics, for a total of 3,282,702 inhabitants in the departments of Caldas, Quindío and Northern Valle del Cauca (NADS - National Administrative Department of Statistics, 2019). The road network in the study area has a total length of $5,464 \mathrm{~km}$, of which $1,269 \mathrm{~km}(23 \%)$ are primary routes, and the remaining 4,195 (77\%) are secondary roads. Figure 3 shows the regional transport infrastructure network and the location of the official Coffee Cultural Landscape routes and airports in the region.

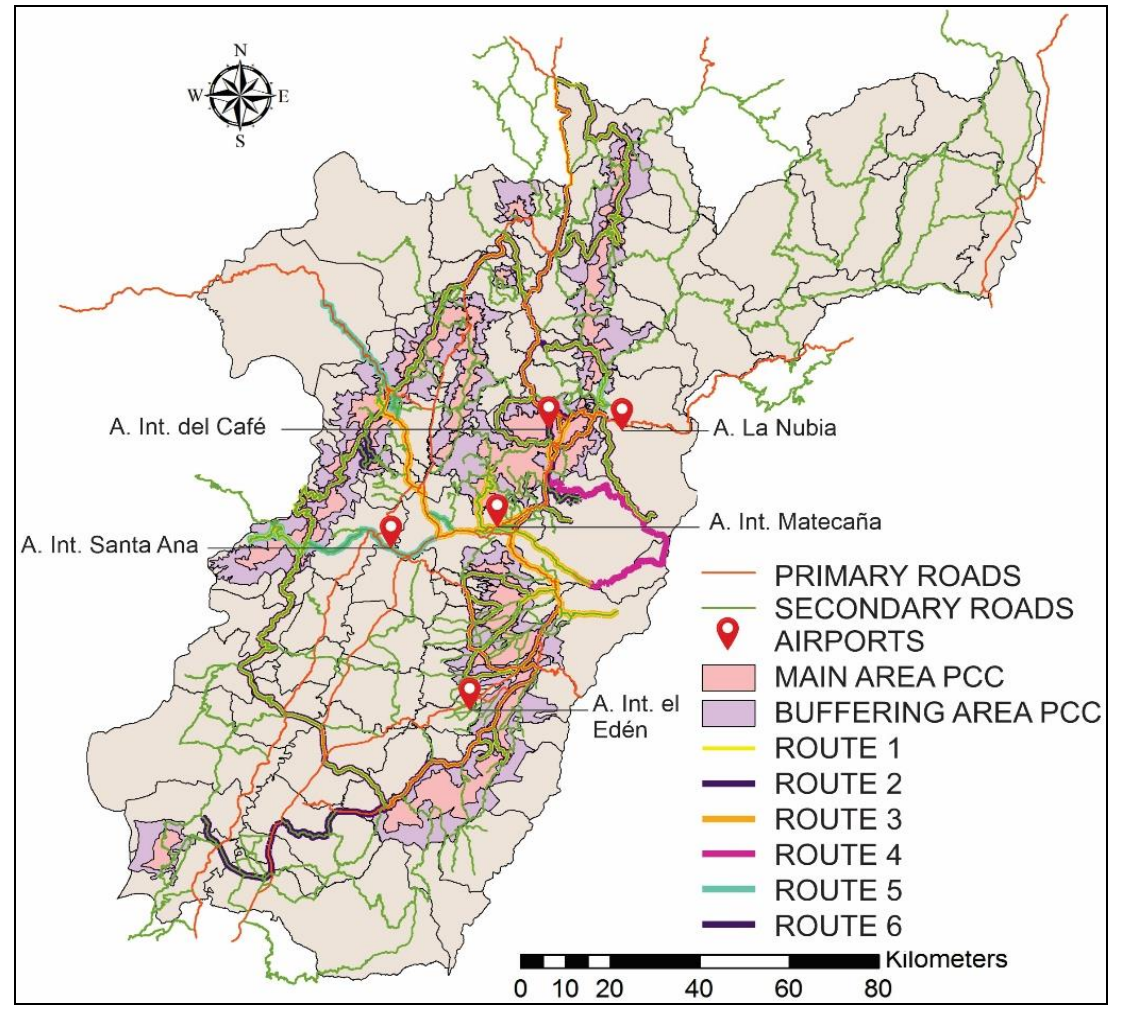

Figure 3. Road network and Coffee Cultural Landscape routes 
Processing network information: From the collected information, the road network and its operational characteristics (speeds, lengths, coordinates) are verified, obtained in the initial stage according to the graph theory (Cardozo et al., 2009) for the calculation of global average accessibility and integral average accessibility to the interest points of the Coffee Cultural Landscape routes.

In geostatistical calculations carried out in previous research, the average operating speeds on the roads corridors are assumed according to the category of the track as follows: Main $60 \mathrm{Km} / \mathrm{h}$, secondary $40 \mathrm{~km} / \mathrm{h}$ and tertiary $30 \mathrm{Km} / \mathrm{h}$ assuming that the operating spe ed on such roads corresponds to the 85th percentile of velocity in each road category (Zuluaga and Escobar, 2017).

This research uses the Google Maps tool ${ }^{\mathrm{TM}}$ " Street view" to get the geographical points of the location of regulatory speeds al ong the main road network corridor Figure 4. They are validated by using real-time modelling tools of the transport system such as Waze and Google Maps, so the estimation of operating speeds is oriented in the operation of light vehicles.

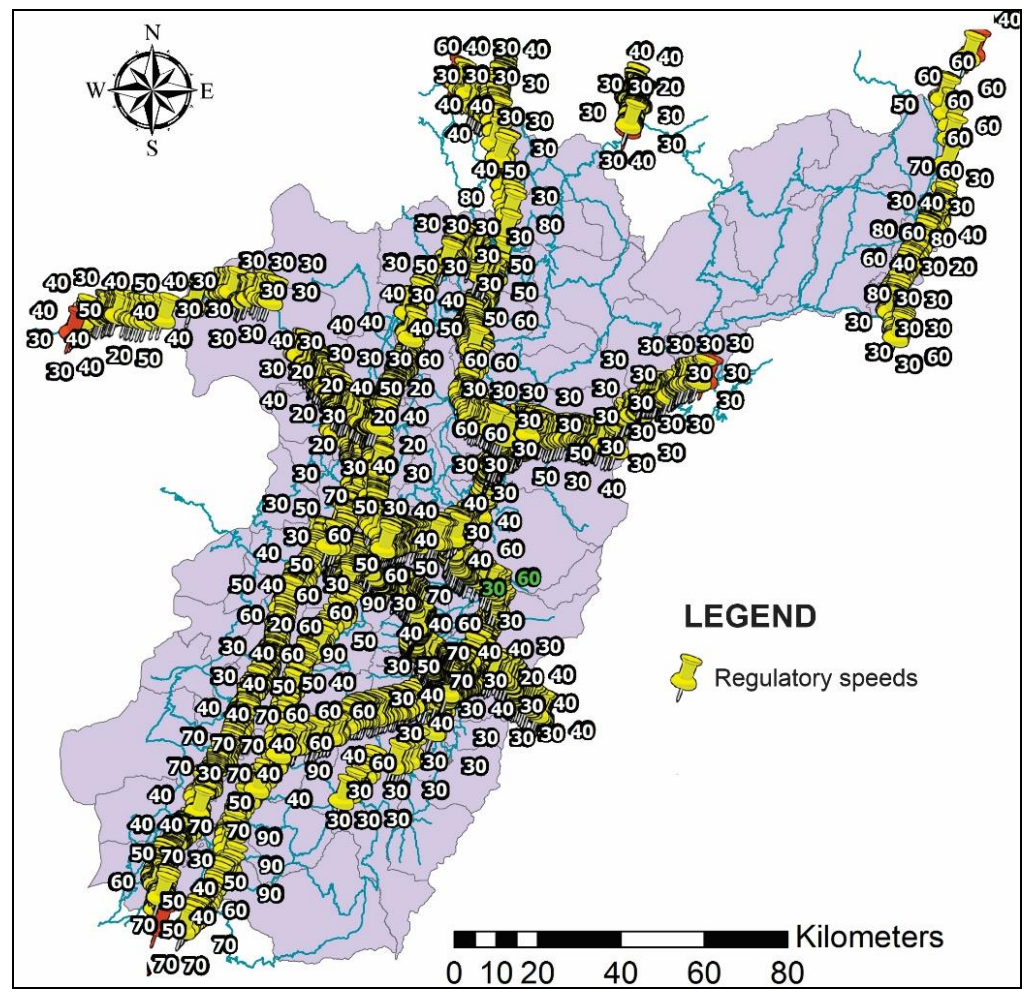

Figure 4. Geographical location of regulatory speeds on the primary road network

Global Average Accessibility Calculation: To estimate the respective global average accessibility isochronous curves and determine the percentage of population coverage that each route has in general concerning the municipalities that make up the Coffee Cultural Landscape, the average travel times from each network node to all the nodes that make up the network are calculated in this stage. For the overall average accessibility calculation, the medium travel time vector must be calculated, using the minimum road algorithm developed by Dijkstra (Dijkstra, 1959), which consists of determining the shortest path between two points by connecting in the form of arcs, in this representation, the road network is made up of nodes and arcs with a given length, so there must be at least one path to reach a node.

The travel time matrix obtained from the implementation of Dijkstra's algorithm contains all minimum routes between each network node (Zuluaga and Escobar, 2017). This matrix allows the calculation of the average travel time vector through the use of Eq. (1), where $\left(\overline{T v_{1}}\right)$ is the travel time average that represents the time that a vehicle takes to travel from the node $(i)$ to the node $(j)$, and $(n)$ is the number

of nodes in the network (Moncada et al., 2018).

$$
\begin{aligned}
& \overline{T v_{1}}=\frac{\sum_{j=1} t v_{i j}}{n-1} \\
& i=1,2,3, \ldots, n \quad j=1,2,3, \ldots, n
\end{aligned}
$$

1, (Source:Zuluaga and Escobar, 2017)

To perform the geostatistical calculation, the Ordinary Kriging model is used (Simpson et al., 2001). This model estimates and models a function that reflects the spatial correlation of data by linearly combining random variables, starting with the Linear Semivariogram Eq. (2) function, where $\left(\overline{\overline{Y_{(k)}}}\right)$ represents the linear semivariogram function, $\left(Z_{(x)}\right)$ variable value in a place with $\mathrm{x}, \mathrm{y},\left(\boldsymbol{Z}_{(x+h)}\right)$ coordinates indicates a sample value separated by a distance $\mathrm{h}$, and $\mathrm{n}$ is the number of pairs separated by that distance. Stressing that, at a shorter distance, the similarity or spatial correlation between observations is greater (Perilla et al., 2018).

$$
\overline{\bar{\gamma}_{(i n)}}=\frac{\sum\left(Z_{(x+h)}-Z_{(x)}\right)^{2}}{2 n} \quad \text { 2, (Source: Perilla et al., 2018) }
$$

The ordinary Kriging method proposes that the variable value can be predicted by a linear combination of $n$ random Eq.(4) variables, where $\left(\lambda_{i}\right)$ is the weight of the original weighting values.

$$
Z_{(x 0)}=\lambda_{1} Z_{(x 1)}+\lambda_{2} Z_{(x 2))}+\cdots+\lambda_{n} Z_{(x n)}=\sum_{i=1}^{n} \lambda_{i} Z_{(x i)}
$$


Integral Accessibility Calculation: In this stage, the average travel times of all nodes to each of the routes of the Coffee Cultural landscape are calculated and also to each of its tourist attractions to determine the integral accessibility from the isochronous curves. The procedure for the calculation of integral accessibility follows the same methodological line used for the calculation of global average accessibility, with the conceptual distinction in which the aim is to obtain the minimum average travel times between each of the network nodes and the particular reference or analysis node. In this case, the points of interest that are part of the official routes of the Coffee Cultural Landscape. The average travel time vector obtained corresponds to the average time ratio between a specific node and the other nodes that make up the analysed transport infrastructure network. From this, geostatistical calculations are performed to obtain the isochronous curves of average integral accessibility.

Coverage Analysis: The population coverage analysis is carried out from the isochron curves obtained from the calculations of global and integral average accessibility and the number of inhabitants of the municipalities of the Coffee Region and Northern Valle del Cauca. In this way, it is possible to determine the percentage of population covered by each isochronic curve and establish the accessibility conditions offered by the tourist routes of the Coffee Cultural landscape to the inhabitants of the coffee region.

Analysis of Results and Conclusions: Based on the results obtained from the overall and integral average accessibility calculation, the analysis is carried out for each of the tourist routes that are part of the Coffee Cultural Landscape. This follows the methodology described above, reaching specific conclusions regarding the accessibility conditions they offer to the Coffee Cultural Landscape.

\section{RESULTS AND DISCUSSION}

Global Average Accessibility: The global average accessibility isochronous curves for the Coffee Region and Northern Valle del Cauca road network are shown in Figure 5, in time intervals of every 5 minutes. The Coffee Cultural Landscape area was covered with average travel times between 162 and 405 minutes.

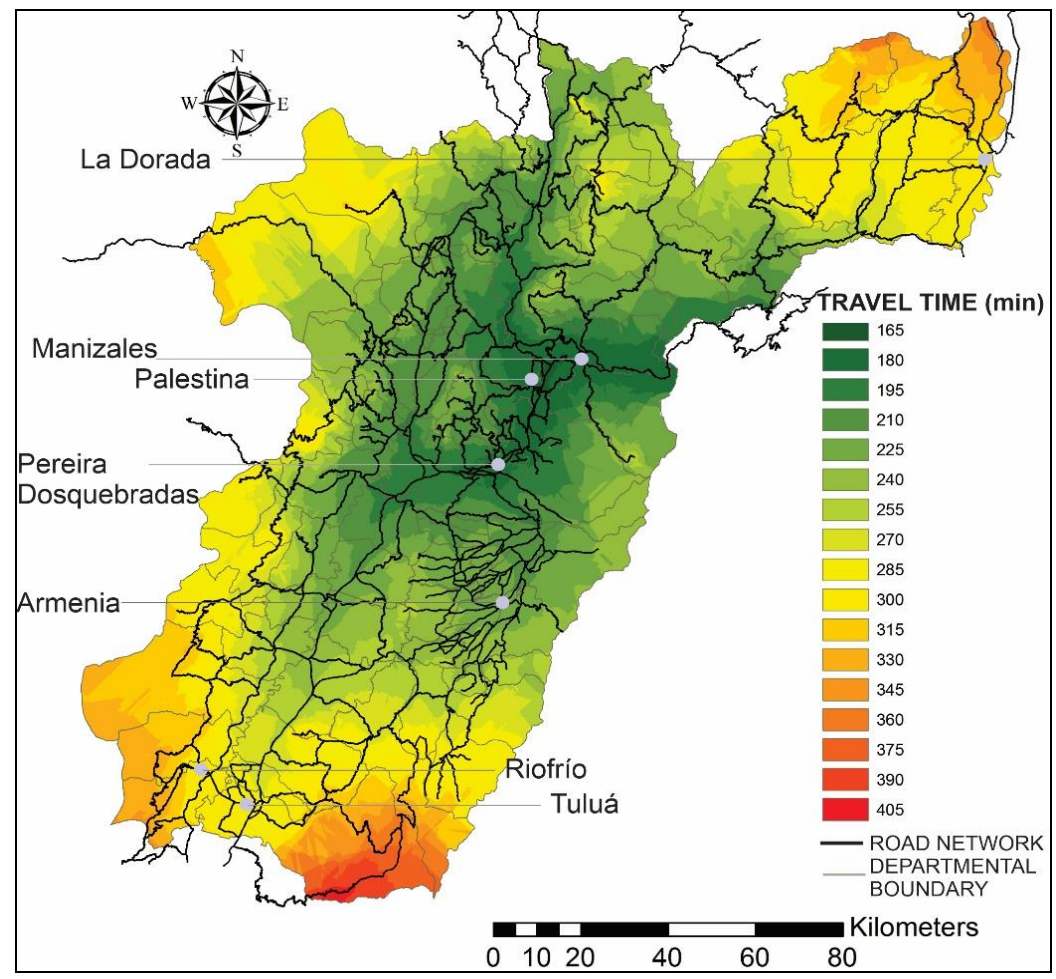

Figure 5. Global average accessibility

The area between the municipalities of Palestine, Manizales, and Pereira shows the best levels of accessibility since the average travel times are between 177 and 183.2 minutes, which represents benefits for the inhabitants of these areas by promoting economic development and enhancing the tourism projection of that region.

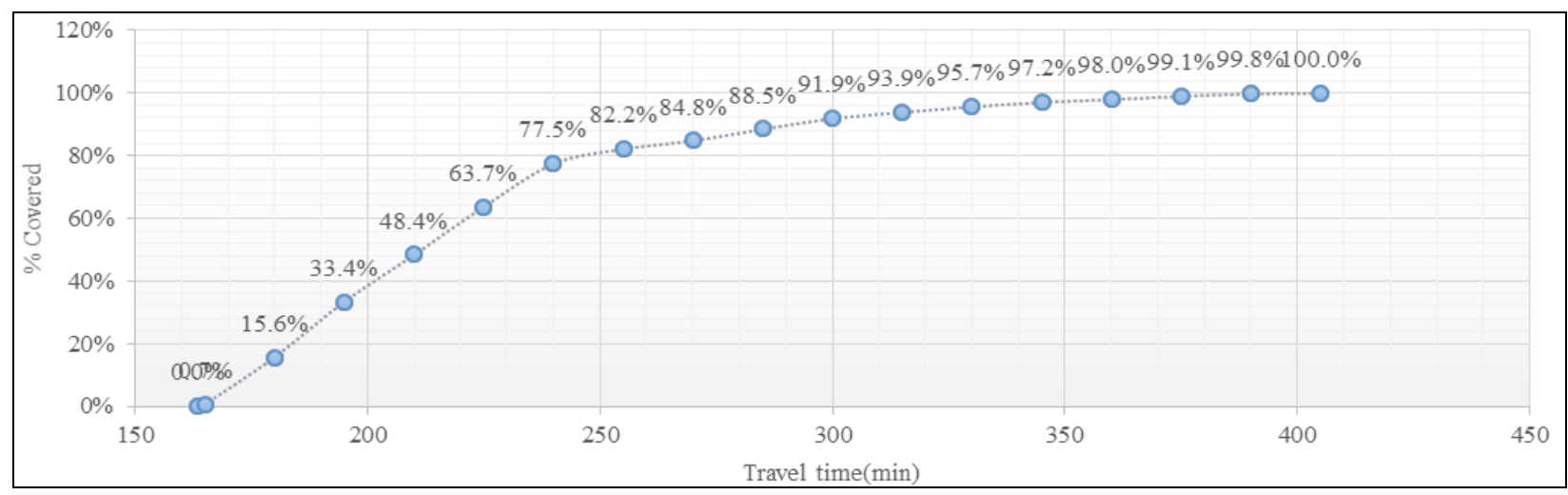

Figure 6. Isochrones curves vs. covered percentage in population 
The shortest average travel time recorded was $162 \mathrm{~min}$, covering a minimal part of the municipality of Manizales. It was also found that for the 227-minute isochronous curve, 3.7\% (121,433 inhabitants) of the study region is covered, being this the curve that covers the largest amount of population. From the overall coverage for the territory that makes up the Coffee Cultural Landscape, it is observed in Figure 6, the cumulative percentage warhead of population. 50\% of the Coffee Cultural Landscape region population is covered with average travel times of up to 212 minutes (three and a half hours), and only $0.67 \%$ of the population reaches times less than 165 minutes.

Figure 7 shows the cumulative percentage warhead of the population by each department of the analysis region. From this, it can be observed that the department with the highest population coverage is Risaralda, followed by Caldas, Quindío, and finally Northern Valle del Cauca. From the figure, it can be determined that $50 \%$ of the population is covered for the departments of Risaralda and Caldas in less than 195 minutes, Quindío in less than 225 minutes, and Northern Valle del Cauca 270 minutes.

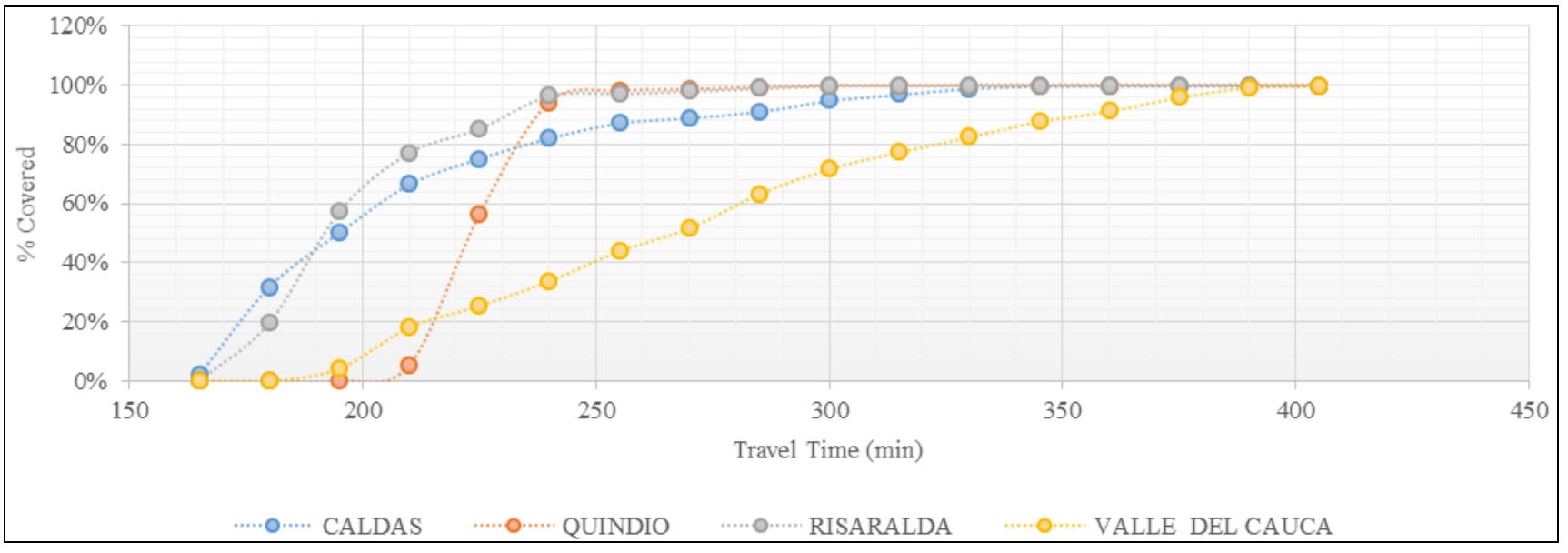

Figure 7. Isochrones curves vs. covered percentage in population by department

It is possible to establish, from the analysis of accessibility by municipalities, that Palestina, Dosquebradas, and Manizales have the best accessibility levels with average travel times between 177 and 179.7 minutes and La Dorada, Riofrío and Tuluá have the worst accessibility indicator with average travel times between 307.5 and 332.3 minutes.

Global Average Accessibility Routes in the Coffee Cultural Landscape: The weighted global average accessibility calculation summary for each of the tourist routes that are part of the Coffee Cultural Landscape is shown in Table 1. It can be seen that route No. 3 shows a better accessibility indicator since the average travel time is shorter than the others, while route 6 shows the longest.

Table 1. Weighted average global accessibility times per CCL tourist route

\begin{tabular}{|l|l|c|c|}
\hline Route & Name & Total length $(\mathbf{k m})$ & Average travel time (min) \\
\hline $\mathbf{1}$ & Charming coffee villages and landscapes & 1151.46 & 217.14 \\
\hline $\mathbf{2}$ & Journey to the origin of the best coffee in the world & 315.95 & 200.04 \\
\hline $\mathbf{3}$ & Exuberant nature and coffee landscape & 269.31 & 188.54 \\
\hline $\mathbf{4}$ & Landscape hiking from 1,000 to 4,000 m & 119.45 & 199.29 \\
\hline $\mathbf{5}$ & Bird watching in the central-western Andes & 318.27 & 199.04 \\
\hline $\mathbf{6}$ & Special coffees, from origin to revelation & 728.43 & 232.55 \\
\hline
\end{tabular}

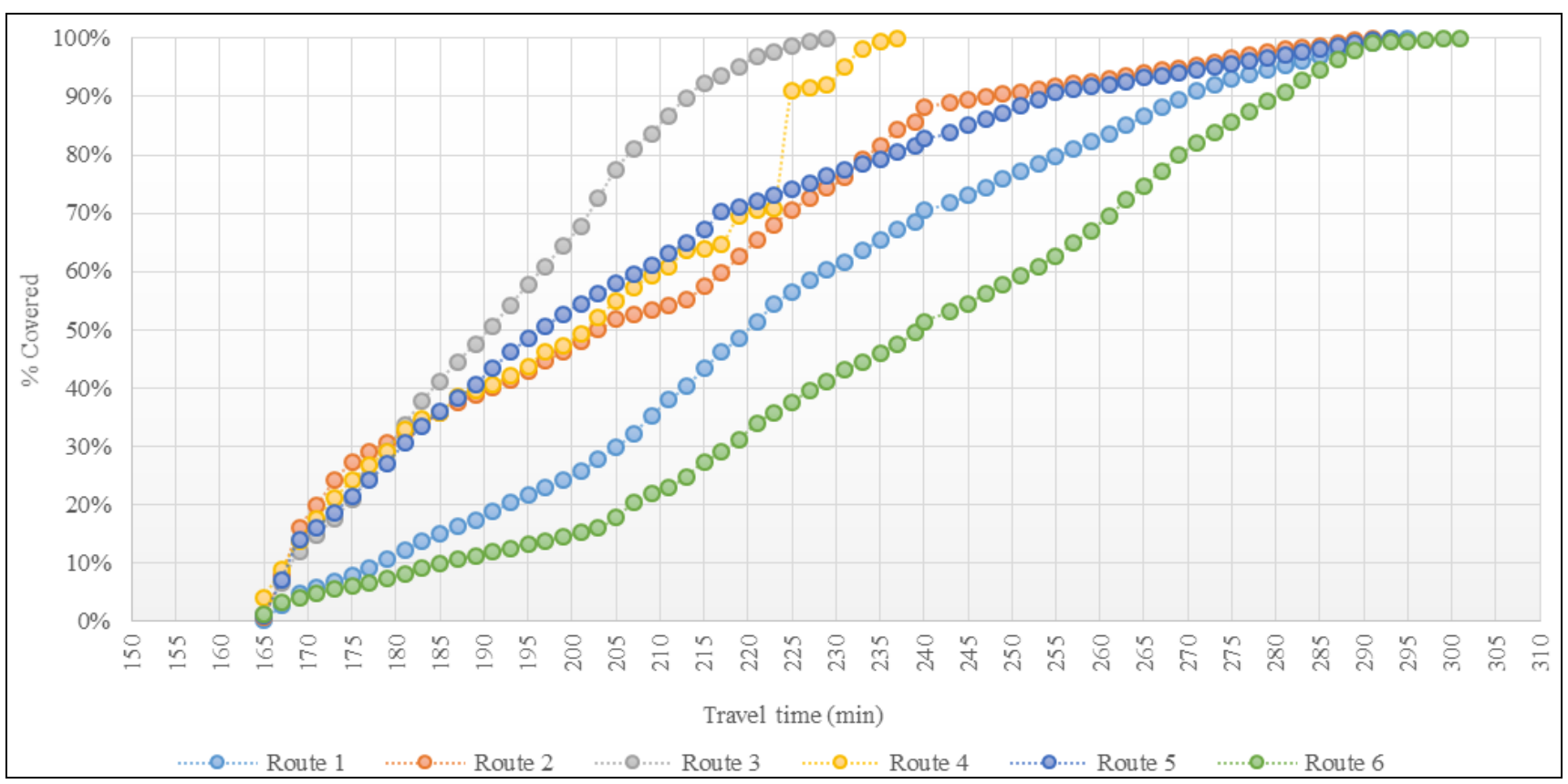

Figure 8. Isochrones curves vs. covered percentage in length by route 
The above can be supported in Figure 8, which represents the cumulative percentage warhead of coverage in terms of route length, for each of the isochronous curves obtained from the global average accessibility analysis.

Integral Average Accessibility: The isochronous curves of integral average accessibility for the points of interest of route No.3 Exuberant nature and coffee landscape- are shown in Figure 9 in travel times at 10-minute intervals, for private vehicle users traveling to each of the points of interest of the analysis route, with travel times prevalence of fewer than 140 minutes.

The cumulative warheads of population coverage, for each of the points of interest in the tourist routes and lodgings of the Coffee Cultural Landscape, are shown in Figure 10, obtained from the integral average accessibility calculation, from which it can be observed that the points of interest that have better coverage and therefore better territorial accessibility are those found on route No.6 and No.3, while points indicated as lodgings within the Coffee Cultural Landscape show the lowest population coverage with longer average travel times.

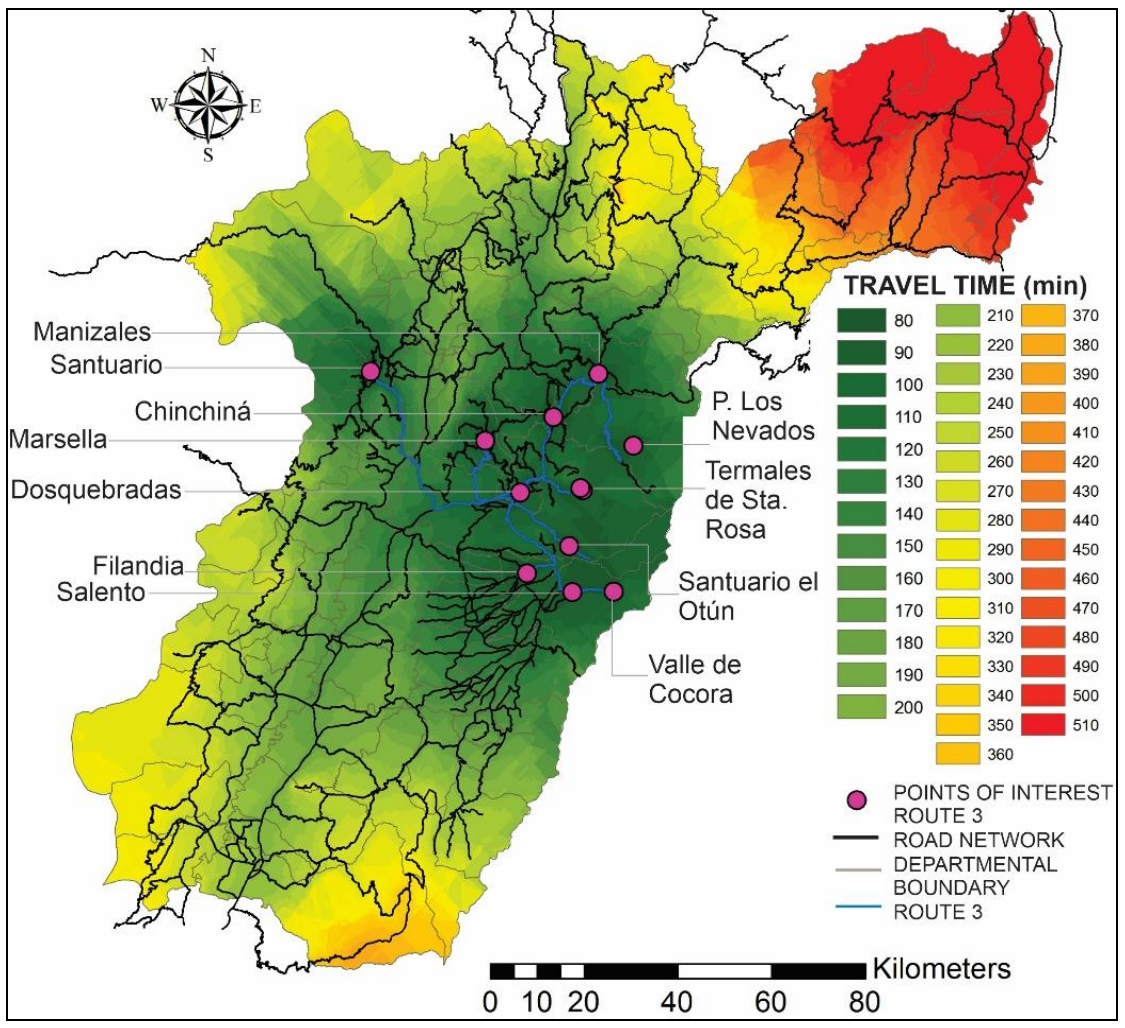

Figure 9. Integral accessibility points of interest in touristic route No.3

The pattern that can be identified from the graphs of percentage warheads accumulated by population and area in the integral accessibility analysis, for each of the routes and farms of the Coffee Cultural Landscape, shows that in a small area, greater coverage is reached in terms of population. This is due to the close location of the urban centers concerning the points of analysis or points of interest on the route. That is, those located in areas of high population density.

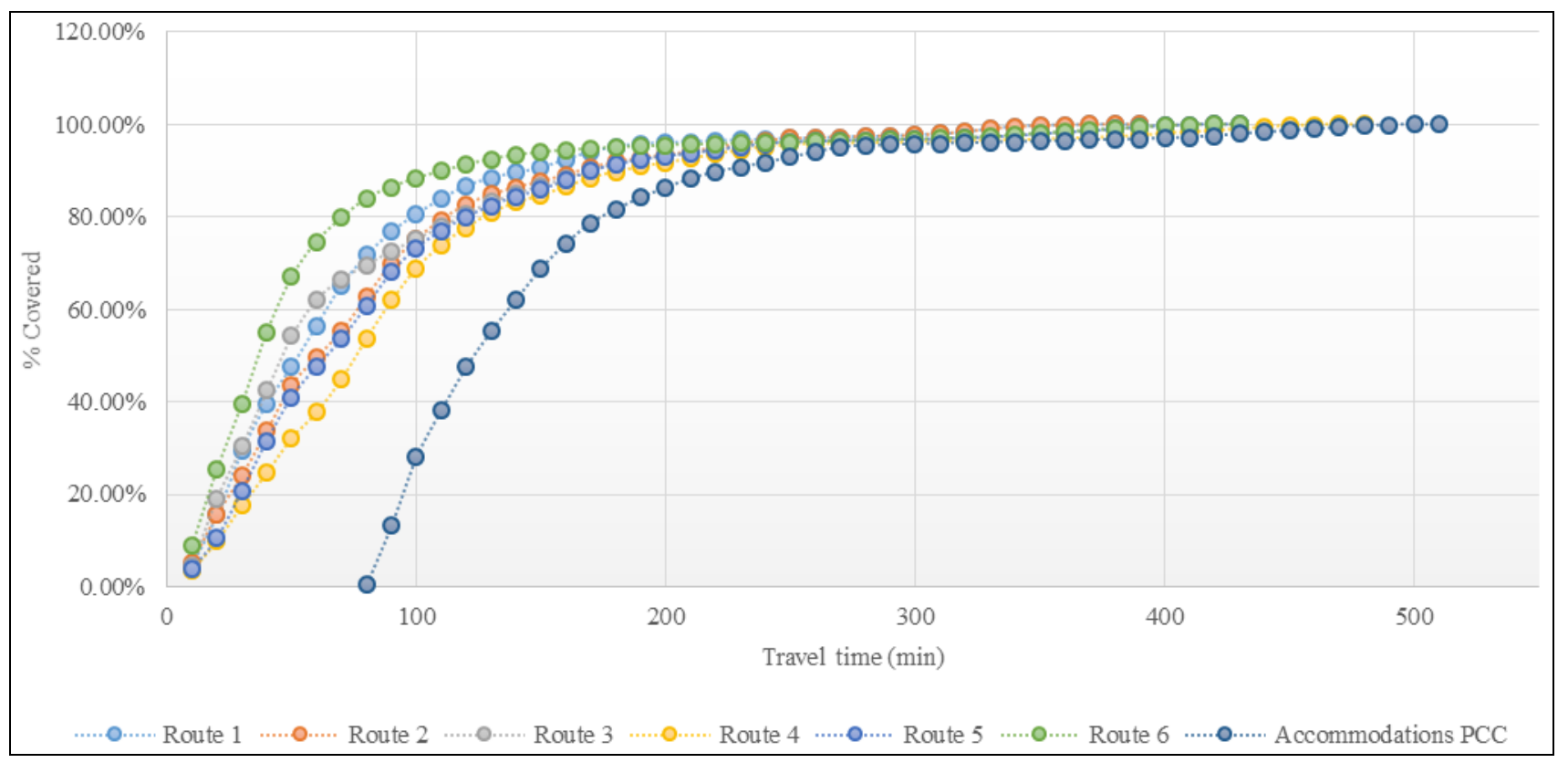

Figure 10. Isochrones curves vs. covered percentage in population for the points of interest on the CCL routes 
There is a comparison in terms of average travel time in Figure 11, obtained from the calculation of average global accessibility and the Gross Domestic Product of the four departments that are part of the Coffee Cultural Landscape, based on information collected from the National Administrative Department of Statistics for the year 2018 (NADS- National Administrative Department of Statistics, 2018, https://www.dane.gov.co/index.php/estadisticas-por-tema/cuentas-nacionales/cuentas-nacionales-trimestrales).

A correlation coefficient equal to -0.288 is obtained for a $95 \%$ confidence level from the multi-varied statistical analysis used to establish the relationship between the average travel time and Gross Domestic Product variables at the departmental level. Indicating that there is a relatively weak relationship between these two variables. In Figure 11, it is possible to observe a direct correlation between Gross Domestic Product and average travel times for the departments of Caldas and Risaralda. However, this connection is reversed by analysing the case of Quindío and Northern Valle del Cauca departments, since the former shows a better indicator of accessibility (resulting in less average travel time) despite counting the worst economic indicator of the four departments.

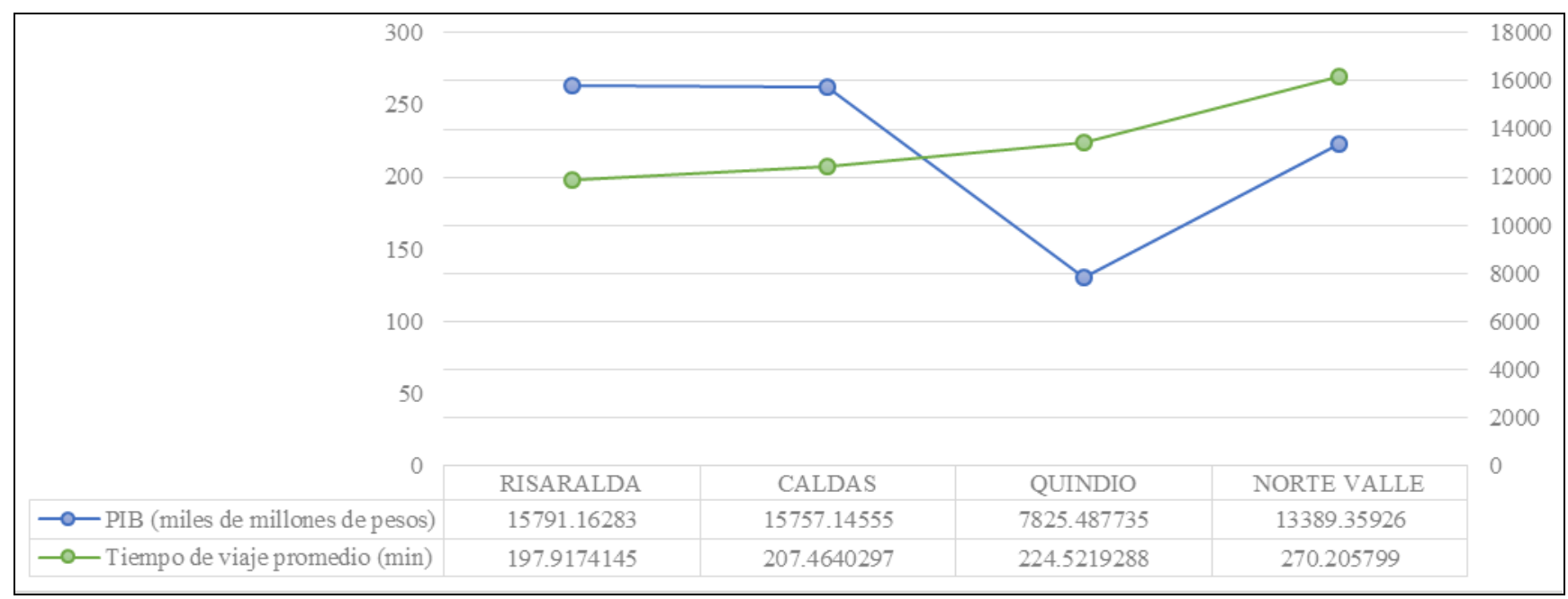

Figure 11. Comparative accessibility - gross domestic product by department of CCL

\section{CONCLUSION}

Based on the results obtained from the statistical analysis between the average travel time and GDP variables, it is concluded that there is a weak relationship between them; when observing at the case of Caldas department where GDP is the highest, the shortest travel time of the four departments analyzed is obtained, this shows that the design of having a better quality of road infrastructure results in better accessibility and positively impacts on economic indicators; however, Quindío and Northern Valle del Cauca this correlation is reversed.

In the search for a connection among the region's tourism potential, the infrastructure features that provide access to the different points of tourism interest and the economic indicators of the Coffee Cultural Landscape region, the hypothesis is that tourism attraction responds directly to the provision of goods, equipment, services and the level of accessibility of the study area; however, when comparing the results obtained in the research between GDP, accessibility and tourism, it can be determined that there is no direct relationship be tween these variables for the departments of the Coffee Cultural Landscape, since the departments of Caldas and Risaralda show better accessibility and economic indicators, have less tourism development in relation to the department of Quindío which has a greater development of tourism in the sector, with lower levels of accessibility and economic indicators (GDP); the above is explained by the low participation of the tourism component in the GDP of the departments of the Coffee Cultural Landscape, with a percentage of 3.7\% of the regional total (Office of Economic Studies, 2020, https://www.mincit.gov.co/getattachment/estudios-economicos/perfiles-economicos-por-departamentos/perfilesregionales/region-eje-cafetero/oee-fp-perfil-region-eje-cafetero-25jun20.pdf.aspx).

Finally, for future research, it is proposed to conduct a project to establish the variables and attributes of the road network of the Coffee Cultural Landscape, which influences both the calculations of accessibility and the development of tourism in the region, so those policies can impact positively on this sector.

\section{Acknowledgement}

This research project was developed in the framework of the Master's Degree in Engineering - Infrastructures and Transport Systems. It was supported by the Sustainable Mobility Research Group - GIMS of the National University of Colombia (Manizales Campus).

\section{REFERENCES}

Bauer, R., Delling, D., Sanders, P., Schieferdecker, D., Schultes, D., \& Wagner, D. (2010). Combining hierarchical and goal-directed speed-up techniques for Dijkstra's algorithm. ACM Journal of Experimental Algorithmics, 15(1). https://doi.org/10.1145/1671973.1671976

Beria, P., Debernardi, A., \& Ferrara, E. (2017). Measuring the long-distance accessibility of Italian cities. Journal of Transport Geography, 62(June 2016), 66-79. https://doi.org/10.1016/j.jtrangeo.2017.05.006

Cardozo, O., Gomez, E., \& Parra, M. (2009). Teoría de Grafos y Sistemas de Información Geográfica aplicados al Transporte Público de Pasajeros en Resistencia (Argentina) [Theory of Graphs and Geographic Information Systems applied to Public Passenger Transport in Resistencia (Argentina)]. Revista Transporte y Territorio, 1, 89-111 (in Spanish).

Celata, F. (2007). Geographic Marginality, Transport Accessibility and Tourism Development. Bologna:Patron, 37-46. Retrieved from https://web.uniroma1. it/memotef/sites/default/files/fcelata_tourismaccessibility_0.pdf

Delling, D., Sanders, P., Schultes, D., \& Wagner, D. (2009). Engineering route planning algorithms. Lecture Notes in Computer Science (Including Subseries Lecture Notes in Artificial Intelligence and Lecture Notes in Bioinformatics), 5515 LNCS, 117-139. https://doi.org/10.1007/978-3-642-02094-0_7

Dijkstra, E. (1959). A note on Two Problems in Connexion with Graphs. Numerische Mathematik, 1(1), 269-271. Retrieved from http://www.bioinfo. org.cn/ dbu/AlgorithmCourses/Lectures/Dijkstra1959.pdf

Escobar, D., Cardona, S., \& Moncada, C. (2018). Integral Accessibility to Airports in the Colombian Coffee Region. Case Study: Coffee Airport, Colombia. Indian Journal of Science and Technology, 11(26), 1-8. https://doi.org/10.17485/ijst/2018/v11i26/129344 
Escobar, D., \& García, F. (2012). Análisis de priorización de proyectos viales Caso Manizales (Colombia) [Prioritization analysis of road projects Manizales Case (Colombia)]. Retrieved from http://www.bdigital.unal.edu.co/10941/6/9789587611298.2012.pdf (in Spanish).

Escobar, D., Garcia, F., \& Tolosa, R. (2013). Análisis de accesibilidad territorial a nivel regional [Analysis of territorial accessibility at a regional level]. Retrieved from https://www.uneditorial.com/analisis-de-accesibilidad-territorial-a-nivel-regional-geografia.html (in Spanish).

Escobar, D., \& Urazán, C. (2014). Accesibilidad territorial: instrumento de planificación urbana y regional [Territorial accessibility: an instrument of urban and regional planning]. Revista Tecnura, 18, 241. https://doi.org/10.14483/udistrital.jour.tecnura.2014.se1.a18 (in Spanish).

Guzman, L., Oviedo, D., \& Cardona, R. (2018). Accessibility changes: Analysis of the integrated public transport system of Bogotá. Sustainability (Switzerland), 10(11). https://doi.org/10.3390/su10113958

Hansen, W. (1959). How Accessibility Shapes Land Use. Journal of the American Planning Association, 25(2), 73-76. https://doi.org/10.1080/ 01944365908978307

Hernández, D. (2012). Activos y estructuras de oportunidades de movilidad. Una propuesta analítica para el estudio de la accesibilidad por transporte público, el bienestar y la equidad. [Assets and structures for mobility opportunities. An analytical proposal for the study of accessibility by public transport, wellbeing and equity]. Eure, 38(115), 117-135. https://doi.org/10.4067/S0250-71612012000300006 (in Spanish).

Hernandez, D., Hansz, M., \& Rubinstein, E. (2018). ¿Qué implica la accesibilidad en el diseño e implementación de políticas públicas urbanas? [What does accessibility imply in the design and implementation of urban public policies?]. Banco Interamericano de Desarrollo, IDB-TN-156(December), 1-53. https://doi.org/10.18235/0001469 (in Spanish).

Higgs, G., Jones, S., Langford, M., \& Heley, J. (2018). Assessing the impacts of changing public service provision on geographical accessibility: An examination of public library provision in Pembrokeshire, South Wales. Environment and Planning C: Politics and Space, 36(3), 548-568. https://doi.org/10.1177/2399654417715457

Ingram, D. (1971). The Concept of Accessibility; A search for an operational form. Regional Studies, 5(June 2012), 101-107. https://doi.org/https:// doi.org/10.1080/09595237100185131

Kastenholz, E., Eusébio, C., Figueiredo, E., \& Lima, J. (2012). Accessibility as Competitive Advantage of a Tourism Destination: The Case of Lousã Advances in Culture, Tourism and Hospitality Research, 6, 369-385. https://doi.org/10.1108/S1871-3173(2012)0000006023

Liu, S., \& Zhu, X. (2004). An integrated GIS approach to accessibility analysis. Transactions in GIS, 8(1), 45-62. https://doi.org/10.1111/j.1467-9671.2004.00167.x

López, F., Marchena, M., Clavé, S., V. J. F. (2011). Análisis territorial del turismo y planificación de destinos turísticos [Territorial analysis of tourism and planning of tourist destinations]. T. lo Blanch, ed. Retrieved from https://dialnet.unirioja.es/servlet/libro? codigo=675851 (in Spanish).

Lucas, K. (2012). Transport and social exclusion: Where are we now? Transport Policy, 20, 105-113. https://doi.org/10.1016/j.tranpol.2012.01.013

Lucas, K., Van Wee, B., \& Maat, K. (2016). A method to evaluate equitable accessibility: combining ethical theories and accessibility-based approaches. Transportation, 43(3), 473-490. https://doi.org/10.1007/s11116-015-9585-2

Moncada, C., Cardona, S., \& Escobar, D. (2018). Saving Travel Time as an Urban Planning Instrument. Case Study: Manizales, Colombia. Modern Applied Science, 12(6), 44. https://doi.org/10.5539/mas.v12n6p44

Montoya, J., Escobar, D., \& Zuluaga, J. (2017). Acceso peatonal y cobertura de las estaciones del sistema de bicicletas públicas de la ciudad de Manizales [Pedestrian access and coverage of the stations of the public bicycle system in the city of Manizales]. Espacios, 38, 8. Retrieved from https://www.revistaespacios.com/a17v38n29/a17v38n29p08.pdf (in Spanish).

Oviedo, D., Scholl, L., Innao, M., \& Pedraza, L. (2019). Do Bus Rapid Transit Systems improve accessibility to job opportunities for the poor? The case of Lima, Peru. Sustainability, 11(10), 1-27. https://doi.org/10.3390/su11102795

Perilla, D., Escobar, D., \& Cardona, S. (2018). New transportation infrastructure impact in terms of global average access - intersection "La Carola" Manizales (Colombia) case study. Contemporary Engineering Sciences, 11(5), 215-227. https://doi.org/10.12988/ces.2018.812

Rosero, L. (2004). Spatial access to health care in Costa Rica and its equity: A GIS-based study. Social Science and Medicine, 58(7), 1271-1284. https://doi.org/10.1016/S0277-9536(03)00322-8

Simpson, T., Mauery, T., Korte, J., \& Mistree, F. (2001). Kriging models for global approximation in simulation-based multidisciplinary design optimization. AIAA Journal, 39(December), 2233-2241. https://doi.org/10.2514/3.15017

Tiwari, G., \& Jain, D. (2012). Accessibility and safety indicators for all road users: Case study Delhi BRT. Journal of Transport Geography, 22, 87-95. https://doi.org/10.1016/j.jtrangeo.2011.11.020

Walsh, S., Cullinan, J., \& Flannery, D. (2017). The Impact of Proposed Higher Education Reforms on Geographic Accessibility to Universities in Ireland. Applied Spatial Analysis and Policy, 10(4), 515-536. https://doi.org/10.1007/s12061-016-9193-3

Xiao, Y., Sarkar, C., Webster, C., Chiaradia, A., \& Lu, Y. (2017). Street network accessibility-based methodology for appraisal of land use master plans: An empirical case study of Wuhan, China. Land Use Policy, 69(September), 193-203. https://doi.org/10.1016/j.landusepol.2017.09.013

Yigitcanlar, T., Sipe, N., Evans, R., \& Pitot, M. (2007). A gis-based land use and public transport accessibility indexing model. Australian Planner, 44(3), 3037. https://doi.org/10.1080/07293682.2007.9982586

Zuluaga, J., \& Escobar, D. (2017). Análisis de accesibilidad territorial de la región noroccidente de Colombia [Territorial accessibility analysis of the northwestern region of Colombia]. Espacios, 38(06), 30. Retrieved from https://www.revistaespacios.com/a17v38n06/a17v38n06p30.pdf (in Spanish).

*** Coffee Cultural Landscape Tourist Information System (SITUR FONTUR). (2019). Informe Turismo Receptor Mayo 2019 [Inbound Tourism Report May 2019]. Retrieved from https://siturpcc.com/informes/ (in Spanish).

*** Ministry of Culture (2009). Plan de Manejo Paisaje Cultural Cafetero [Cultural Coffee Landscape Management Plan]. Retrieved from http://paisajeculturalcafetero.org.co/contenido/Plan-de-Manejo-del-PCC (in Spanish).

*** Ministry of Culture (2011). Paisaje Cultural Cafetero: un paisaje cultural productivo en permanente desarrollo [Coffee Cultural Landscape: a productive cultural landscape in permanent development]. Retrieved from http://paisajeculturalcafetero.org.co/static/files/cartillaministerio.pdf.pdf (in Spanish).

*** NADS- National Administrative Department of Statistics. (2018). Gross Domestic Product (GDP) base 2015. Retrieved September 20, 2012, from https://www.dane.gov.co/index.php/estadisticas-por-tema/cuentas-nacionales/cuentas-nacionales-trimestrales (in Spanish).

*** NADS - National Administrative Department of Statistics. (2019). Proyecciones y retroproyecciones de población [Population projections and back projections]. Retrieved from https://www.dane.gov.co/index.php/estadisticas-por-tema/demografia-y-poblacion/proyecciones-de-poblacion (in Spanish).

*** Office of Economic Studies. (2020). Información: Perfiles Económicos Regionales. In Ministerio de comercio industria y turismo de Colombia [Information: Regional Economic Profiles. In Ministry of Commerce, Industry and Tourism of Colombia]. Retrieved from https:/www.mincit.gov.co/getattachment/estudios-economicos/perfiles-economicos-por-departamentos/perfiles-regionales/region-eje-cafetero/oee-fpperfil-region-eje-cafetero-25jun20.pdf.aspx (in Spanish) 